\title{
Rethinking Language, Arts and Culture in an Evolving Democracy
}

\author{
Emeka C. Ifesieh \\ Department of Languages and Linguistics, \\ Delta State University, \\ P.M.B. 1, Abraka, Delta State, Nigeria
}

DOI: https://doi.org/10.36941/ajis-2021-0050

\begin{abstract}
Democracy has been acclaimed as the best form of government practicable. Its core essence is that the authority of the government is a trust, which is lost once the government becomes a danger to the governed. Power-elites in evolving democracies, especially Nigeria, a pivotal state, consisting of north and south political divides, generate conceptualisations, (i.e., language: arts and culture) for sustenance of inequality. Using the heterogeneous purposive sampling, 7 texts produced by power-elites of Nigeria are selected and subjected to critical discourse analysis (CDA). The core assumptions of CDA are: language is both the site for power struggle and the instrument for domination and inequality. The Muslim northern Nigeria power-elites coercively dominate access to political discourse. The marginalised southern participants should strategically rethink their language to gain access to political discourse in the evolving democracy.
\end{abstract}

Keywords: language, conceptualisation, power-elite, dominance, inequality, reconceptualisation

\section{Introduction}

Language is a set of arbitrary symbols with which a sociocultural group communicates and interacts. Interaction and communication involve exchange of meanings. The carrier of the meanings in human communication and interaction is the symbol. Some symbols are not vocalized yet, they qualify as language. For example, art forms, dance, dress codes, paintings, costumes and assorted behavioural modes such as signs and non verbal cues. Ogden and Richard (1946:11) suggest that there is no direct relationship between the symbol and the signified or referent, i.e., language in the real world. The relationship is actualized through thought or reference, i.e., the concept in the mind of the language user. At the socio-cultural level, the concept meaning is established by public consensus. Subsequently, language connects fundamentally to the human essence, the innate and distinctive qualities of the mind's ability to linguistically conceptualise and ascribe semantic values to symbols.

A symbol is sign with multiple layers of meanings. It can suggest more than it denotes, for it usually possesses three kinds of associations: personal, socio-cultural and universal (Ifesieh, 2013: 49). Consequently, the art forms, dress codes, paintings, costumes and diverse behavioural modes are all deployable symbolic conceptualisations of mind. In the same vein, art: liberal or fine, "the use of skill and imagination in the creation of aesthetic objects, environment, or experiences which can be shared with others" (Safra, 2010 : 594 ), is also a part of language.

To Halliday (1978: 109), language is a 'social semiotic'. By 'social semiotic' is meant 'a social system 
or a culture' which he refers to as 'a set of semiotic systems, i.e., a set of systems of meaning all of which interrelate' (Halliday and Hasan, 1991: 4). Haralambos, Holborn and Heald (2008: 664) describe the 'culture of a society as the way of life of its members, the collection of ideas and habits which they learn, share and transmit from generation to generation'. It is clear that language is implicated in this description. Invariably, democracy which is a human conceptualisation, which is an aspect of culture, is equally part and parcel of language.

A concise explanation of the meaning of democracy is offered here, because it is the independent variable at which art and culture converge. According to Safra $\left(2010^{\mathrm{b}}: 5\right)$ the concept has three fundamental senses in the contemporary application:

"i. A form of government in which the right to make political decisions is exercised directly by the whole body of citizens, acting under procedures of majority rule, usually known as direct democracy; ii. a form of government in which the citizens exercise the same right not in person but through representatives chosen by and responsible to them, known as representative democracy; and iii. a form of government usually a representative democracy in which the powers of the majority are exercised within a framework of constitutional restraints designed to guarantee all citizens the enjoyment of certain individual or collective rights such as freedom of speech and religion, known as liberal or constitutional democracy".

One thing can be culled out from the three senses: the ultimate authority in political matters rightfully rests on the citizenry. This portends that the decisions of government with regard to the directions of policy is determined directly or indirectly by the freely given consent of the majority of the adult governed. For democracy to thrive, the adult citizenry should be informed, because only informed citizens can make responsible choices (Rottenberg and Winchell, 2006); there should be citizen participation; there should be delegation of power; there should be individual liberties and inviolable rights for minorities (Encyclopedia Americana: International Edition, 2004. Vol. 8: 684-691).

Africa can be typified as a continent where democracies are evolving. Nevertheless, the evolving democracies are characterized by participant domination and resistance: the people in power oppress their subjects, especially through monopolisation of access to power discourse. The subjects in turn attempt a resistance to the oppression. Instances: in the $80 \mathrm{os}, 80 \%$ of the economy of Zambia was in Kaunda's hands under a one party state. This is tantamount to 'state capture probably by a cabal' (Omotor, 2019). There was social and economic decay. This sparked off protests and formation of Movement for Multi-party Democracy (MMD) in the eastern province of Zambia (Banda, 2002: xiixiv). The impact of Kaunda's misrule is noticed in conceptualisations and linguistic structures of the Zambians up to this day (cf. Larmer, 2002: 157-177). With the deconstruction of the apartheid ideology and dismantling of the apartheid regime in South Africa (Cornevin, 1981), the political right of the black majority was recognized. Consequently, the black participant came to power through the African National Congress Party (ANC). Nevertheless, the performance of ANC participants was a disaster: between 1994 and 1998, millions of jobs were lost; GDP fell from 3.5 to 0.1 (Dwyer, 2002: 196). Sequel to that, there was hardship which gave rise to uprisings. The political situations in Egypt and Zimbabwe are not significantly different (cf. Alexander and Renton, 2002: 87-115; Gwisai, 2002: 219-251). Rwanda and Burundi are described as war-torn countries, all in Africa.

Therefore, it is problematic that politics and democracy in Africa are characterised by injustice and repression, which breed forms of violence noticed in both the language and actions of the participants in the polity. Subsequently, there is a great deal of expectations on Nigeria, referred to as the giant of Africa due to its huge human and natural resources. The current estimate of Nigeria's population is 200 million. It is projected that by the turn of the $21^{\text {st }}$ century, Nigeria's population would be about 250 million. Nigeria exerts an enormous sociocultural and political influence on not only the West African sub-region, but also on the entirety of Africa and by proxy the globe. Subsequently, it can be considered a pivot state (cf. Sweijs, Oosterveld, and Knowles and Schellenkes, 2014). Being a pivot state makes it a good specimen to zero-in on for this write-up, because what happens in Nigeria has far-reaching implications, particularly in Africa, then in the world generally. Sequel to that, the objective of this article is to demonstrate that ideology of injustice and repression can be apprehended 
and dismantled by a critical examination of language use of power-elites in politics. Then, it can be challenged through a re-conceptualisation of the political discourse by the participants in other to achieve an equitable polity.

\section{Conceptual Framework}

Culture and arts constitute integral parts of the semiotic system, i.e., language which is a human conceptualisation. Democracy being a political culture is also a part of the semiotic system. Since culture, including political culture and arts are all necessary components of the semiotic system, they can be reconceptualised in accordance with the context of the situation. The participants in the context of situation, i.e., the polity, make conceptualisations which they linguistically symbolize and apply on fellow participants. Reconceptualisation or rethinking the semiotic system becomes decisively necessary once the component(s) of the system fail(s) to support the general good of the majority of the polity or in a situation of desire for improved performance.

\section{Political Background to the Problem}

Besides the increasing demand for democracy as the best form of government, the intensified unpopularity of the colonial imperialistic regime also gave an impulse to the agitation for independence and democratic experimentation in Nigeria. With the attainment of self-rule in 1960, the condition was apparently conducive for Nigeria's democratisation. It began. However, the colonial imperialism had left behind a heritage of bureaucratically manipulated economy fundamentally tailored towards extraction of raw materials for foreign markets. Although it is important to underscore the essentiality of the independence, it is equally note-worthy to mention that the ordinary workers were exploited; they were poorly paid (cf. Viinikka, 2002:129). In other words, imperialism continued in a new nationalist garb. The civilian nationalist, exploitative and corrupt government created the field for the military to take power, which of course happened in January 1966. Series of coup d'états happened with each government promising change and good governance only to perform worse than the one it toppled. The military regimes were characterized by decrees, human right abuses, manipulation of the judiciary, gag-orders and social crises. There was a civilian interregnum of Alhaji Shehu Shagari which was sacked by General Muhamadu Buhari's coup d'état, who was in turn, militarily ousted by General Babangida Ibrahim. By popular resistance and demand for the reinstallation of a civilian government, General Babangida was pressured to step aside. Mr. Ernest Shonekan was to organise an election to hand over the affairs of the country to a democratically elected president, but his interim government was toppled by General Sani Abacha, who suddenly died in office. General Abdulsalami Abubakar who replaced him was saddled with the responsibility to organize an election within 6 months of assumption of office to hand over to a democratically elected president. The arrangement brought in President Olusegun Obasananjo as Nigeria's president on $29^{\text {th }}$ May, 1999 under the auspices of Peoples Democratic Party (PDP) as the party in power. It is essential to mention that PDP is a strong party in Nigeria because both its financial and political bases are strong: many of the ex-military presidents and governors who are also predominantly from the northern Hausa-Fulani oligarchy support the party. From 1999 to this moment, Nigeria has been practicing democracy. The various coup d'états and the seesaw movements between the military and civilian regimes occasioned by political misrule, are all indicative of a state with a chequered political history.

Within the country, misrule is usually characterized by disregard for the rule of law, criminality, embezzlement, corruption, repression, political killings, gag-orders, insurgencies, demonstrations, political assassinations, pipeline vandalism, political incarcerations, job losses, hate speeches, criminal silence, executive impunity, terror attacks, misery, high infant mortality rate, epidemic and pandemic. These are all unpalatable and problematic experiences, which are noticed in the language which subsumes the art and culture of Nigeria's evolving democracy. As instances, Okri (1996) and Iyayi (1980) variously use picaresque episodes to portray the hopelessness, precariousness, meaninglessness, 
irrationality and avarice that pervade post independent Nigeria and Africa by extension. Consequently, there should be a rethinking or re-conceptualisation of language in the political discourse of the nation.

\section{Rethinking Language in an Evolving Democracy}

Rethinking a language may suggest a reinvention of or modification of the language in use. However, that is not actually the case here. Viewed from another angle, if a language is modified to become politically correct, yet the situation and the participants in the context of the situation remain unchanged, then no real change has happened. In both theoretical and practical terms, once a language is used in a context of situation, three features apply: (1) field of discourse - refers to the event taking place in which language plays a role; (2) tenor of discourse - refers to the participants, their status and roles in the discourse, the kind of relationship existing among the participant and (3) mode of discourse - language role including style and text types such as expository, didactic, persuasive, imperative, monologue and dialogue (cf. Halliday and Hassan, 1991; Halliday, 1978).

Sequel to that, the participants comprise the problem in politics. This is demonstrable in the evolving democracy. The participants make conceptualisations and linguistically symbolise them. Then, they go ahead to use the conceptualisation on fellow participants (Halliday, 1985; 2004). If the conceptualisations are good, they generally elicit good responses and bring about positive changes in the polity. If the ideas are bad, then bad responses and effects are produced to the detriment of the participants. Therefore, rethinking a language in an evolving democracy will involve the participants who use the language. Such a rethinking relates to how the language is used; why it is used in the manner it is used and when it is used (cf. van Dijk, 1997: 2); then, it goes ahead look into dominance, power abuse and social inequality. It is this examination of power abuse and inequality that marks the point of departure between CDA and DA (cf. van Dijk, 1993). Dominance and abuse of power are conterminous, for the consequence of either of them is social inequality.

Central in every discourse is the functional nature of language. Function is an inherent feature of language which energises it for every type of application such as communication of political ideologies and all forms of interactions, including political participation. It is this language function that Whorf refers to in the Sapir-Whorf hypothesis. Sapir-Whorf hypothesis stipulates that language determines thought (linguistic determinism) and that difference in language entails differences in thought (linguistics relativity) (cf. Malmkjaer, 2002: 346-347). However, this view is seriously criticised by linguists such as Pinker (1994) and Chandler (1994). Both Pinker and Chandler suggest that the causality 'stance' (Banes, 2018: 36; Rojo and Molina, 2018: 672-695) taken by Whorf in the hypothesis smacks of illogicality, because if language determines people's worldview, then deaf-and-dumb adults would not be able to communicate their experiences and interact meaningfully, but the reverse is the case. Then, the possibility of translatorial action would have been foreclosed, because different linguistic groups perceive the world differently. However, experiences show that translation happens between languages of different phylaphylums. Thus, linguists jettison the linguistic absolutism of Whorf and adopt moderate Whorfianism which emphasises the potentiality to be modified rather than being unavoidably determined by language. The modification is not ascribed to language, but rather to the contextual application of language by the participants. Language is not seen as causality. Rather, certain social-contexts can constrain the participant to display an unnamed linguistic behaviour.

Conceptual representation is triggered off by memory, perception and creativity. Then, it is moulded in the conceptualiser at the pre-verbal stage. Sequel to that, the conceptual representation, also known as conceptualisation goes to the utterance formulator stage where it is constrained according to the morpho-syntactic, lexical and phonological rules of the language and subsequently articulated, written or signed (cf. Tomlin, Forrest, Pu and Kin, 1997: 63-111; Goddard, 1998; Maffi, 1999). An inimical socio-semiotic context is perceptible to the senses and can cause a re-conceptualisation to begin in the memory, especially in a situation of systemic collapse or in a situation of desire for improved performance. Such socio-semiotic re-conceptualisation may be essential for redressing the collapse or for improved performance. Politically, conceptualisations should advance progressive 
opinions and policies which propagate fundamental human rights such as the right to life, equality before the law, property, freedom of worship, freedom of expression and the right to education which are the hallmarks of constitutional democracy. This would imply the entrenchment of good governance in politics-a power structured grid whereby a person or a group of persons controls the activities of others (Ifesieh, 2018: 81). This relates to observance of fundamental human right. A right is a thing to which a person has a proper claim. The person can claim its ownership and usage (cf. Dzurgba, 2008:9).

Subsequently, re-conceptualisation of systems of meaning with defined set objectives is not new in human history: the Arab spring, otherwise called Arab revolt brought about change of government among the Arabs recently (Noueihed and Warren, 2012; Howard and Hussein, 2013). The writings of Thomas Jefferson (1743-1826), Jean-Jacques Rousseau (1712-1778), Karl Marx and Frederick Engels and many more (Blaisdell, 2003) are all indicative of the fact, that at point in a people's socio-cultural history, they may necessarily retrieve themselves from slavery and tyranny or die (Desmoulins, 2003: 67-69; Danton, 2003: 90-91; Voltaire, 2002: 36-40; Proudhon, 2003: 102—122; Bakunin, 2003: 187199; Trotsky, 2003: 204-212; Lenin, 2003: 227-231; Guevara, 2003: 265-279).

Various political thinkers have propounded several political models to guide political behaviour of participants in any polity. However, it is important to note, that the ideas of the thinkers complement one another. Whereas Thomas Hobbes' objective in his writing is to show that the only solution to the consequences of political conflict was an absolute and undivided sovereignty (Hampsher-Monk, 2006: 2), the main focus of John Locke's (1632-1704) argument is to show a right to resistance and the circumstances under which it can be carried out. For Locke, humans are centres for rights and responsibilities. Thus, human establishment of political authority happens in two stages: all men agree to form a political community and to accept the form of government the majority decides to adopt. Next, the community establishes a government, which involves entrusting the rights of judging and executing the law to a man or body of men. Sequel to that, government is a trust, not a simple contract. The body which does the entrusting is the polity, which is the consequence of the contract. Consequently, the government derives its authority from the people (i.e., the community). Therefore, rulers who have infringed the objectives of governance in such a way as to pose a danger no longer exercise authority; they may have power, but they have lost their right of legitimacy in governance. It is properly they who are rebels. Resistance to such rulers is not resistance to authority, for authority exists only where force and right coincide (Hampsher-Monk, 2006: 114; cf. Appadorai, 2004: 25). JeanJacques Rousseau's (1712-1778) view is a synthesis of Hobbes and Locke's opinions: that there was only one contract in which the government was not a party; that individuals surrendered all their rights; having made the contract, they have only the rights allowed by law; that government is not absolute, but sovereignty is, i.e., the community (cf. Appadorai, 2004: 27-28). Many more political thinkers contributed a great deal in moulding the concept of politics as practiced in the contemporary time. Hamilton, Madison and Jay suggest in the "Publius": the Federalist that in politics ambition should be made to counteract ambition; i.e., the interests of participants must be connected with the constitutional rights of the people. Sequel to that, seeking institutional means to cope with human interests should be a core conception of constitution making (cf. Hampsher-Monk, 2006: 239). The views of these political thinkers and many others like David Hume, Edmund Burke, Karl Marx, G.W.F. Hegel, John Stuart Mill and Jeremy Bentham contribute variously in the conceptualisation of constitutional democracy as it is practiced today in different parts of the world.

Nevertheless, democracy as a system of government under President Muhamadu Buhari is been severely criticized. His regime manifests ignorance as it pays attention neither to quantity and nor quality. For example, the 2019 general elections in which Buhari ran for the presidency and was declared the winner by the Nigerian Independent National Electoral Commission's (INEC) chairman, Mahmood Yakubu, was described by the European Union Election Observation Mission NIGERIA 2019 as "marked by severe operational and transparency shortcomings, electoral security problems, and low turnout. ... Fatalities escalated and the role of security agencies became increasingly contentious". https://eeas.europa.eu/sites/eeas/files/nigeria_2019_eu_eom_final_report-web.pdf.

Similar information was also given by many other agencies that observed the election (cf. IRI/NDI 
Nigeria International Election Observation Mission Final Report June 2019: https://www.iri.org/sites/default/files/nigeria_election_report_updated.pdf; https://www.sunnewsonline.com/2019-electoral-violence-worse-than-2015-eisa-eom/; https://dailypost.ng/2019/o2/25/nigeria-elections-international-observer-group-gives-damningreport/). The regime is also being accused of disregard for the rule of law, fragrant disobedience to court judgements/orders, non-observance of due process, ethnicisation and islamisation of federal ministries. Nevertheless, a great preponderance of Nigerians believe that under pleasant conditions Nigerian democratic experimentation would encourage brilliance, self-reliance, civic and social sense of free men placing duty of government on the citizenry, so that the government's authority is considered a trust. Once the thrust is breached, then the government can be resisted. Therefore, it is considered practically a much better form of government than the rest practiced in the Nigerian history: colonialism and military dictatorship.

\section{Methodology}

The purposive heterogeneous sampling is used for data collection. 7 heterogeneous texts produced by power-elites in Nigeria are purposively extracted from the print media publications. In selecting the data, it is borne in mind that the socio-political condition is common to all the texts (cf. Adejare, 1992) and that saturation is attainable with the 7 (cf. Glaser and Strauss, 1967; Creswell 1998). Nevertheless, the attainment of saturation here does not imply that the data analysis is exhausted, because symbols have surplus meanings and are liable to multiple interpretations; interpretations also vary from socioculture to socio-culture (Ifesieh, 2013; van Dijk, 1993). For in-depth comprehension and ample interpretation of structures of dominance and in equality which contravene democratic tenets, the data is subjected to critical discourse analysis (CDA). CDA declares that every linguistic application bears and propagates certain ideological structures through which it mediates a representation of the world; that language is both the site and stake in the struggle for power and dominance, so that access to discourse control is critically necessary for the propagation of certain versions of reality. By dominance is meant exercise of social power by elites, institutions and groups which result in different forms of inequalities (van Dijk, 1993: 483-484). CDA also suggests that language use neither portrays an objective world nor a reflection of equality; rather it demonstrates forms of hegemony, dominance and inequality (Fairclough, 2001; 1995; Locke, 2004; Bloor and Bloor, 2007; Malmkjaer, 2002; van Dijk, 1995; 2006; 2008; 2009; Sheyholislami: http://www.carleton.vjsheyhol/cda.htm).

CDA as applied here engages eclectic approach due to its multidisciplinary nature. The Hallidayan functional approach to clausal description (Halliday, 2004; 1985), traditional descriptive grammar and the interaction principle of metaphor (Black, 1979) are all deployed in the analysis. The investigation variously relates to these discourse dimensions: setting, genre, access, communicative acts and social meanings, participants' positions and roles, speech acts (assertions, allegations, imperatives and accusations), topics, argumentation, coherence, levels of specificity and completeness, perspective, implicitness, style and rhetoric (van Dijk, 1993: 249-253). The critical targets are the power elites that promulgate, propagate, legitimate, accommodate and overlook social inequality and injustice through their linguistic applications. Procedurally, what are said - the actual texts of the power elites or the responses to them are critically examined.

\section{Data Presentation and Analysis}

i. "The new nation called Nigeria should be an estate of our great grandfather Othman Dan Fodio. We must ruthlessly prevent change of power. We use the minorities in the north as willing tools and the south as a conquered territory and never allow them to rule over us and never allow them to have control over their future". (Parrot Newspaper, Oct. 12, 1960)

The statement above was made by the then Saduana of Sokoto, Sir Ahmadu Bello eleven days 
after the declaration of Nigeria's independence. Sir Ahmadu Bello, Hausa-Fulani (northern Muslim) could be considered a great Islamic scholar whose political influence spanned the entire northern Nigeria. The earliest university built in the northern Nigeria was named after him, i.e., Ahmadu Bello University (ABU), Zaria. Therefore, a statement coming from his lips should be taken seriously. In the text, Bello signals dominance by positive self-presentation and negative other-derogation and thereby stipulates the way his fellow northerners and Hausa-Fulani Muslims should relate with the participants in the other sections of the country. With the exception of the first clause which is a passive construction wherein the Agent participant is obfuscated together with past tense of the transitive verb, 'call', 'a verbal processes' (Halliday, 1985; 2004), material action processes pervade the entire text. In the subsequent clauses he makes his conceptualisation clear through the material action processes: "ruthlessly prevent", "use" and "never allow". He perceived Nigeria from Islamic perspective and anaphorically sought to reinforce the charge of the prophet of Islam, Mohammed: that Jihad is a religious duty prescribed by the Quran and approved by the Sunna, i.e., he indirectly made jihad a topic. His diction is specific and shows clearly the obligation to deploy force in the maintenance of dominance of Hausa-Fulani Muslims over the other ethnic nationalities and religious groups in the country. This is evident in the use of the phrase 'must ruthlessly prevent...' Thus, he already conceived the entirety of Nigeria as the 'Abode of Islam' (Hunwick, 1966: 291-307; Karsh, 2007). Derogatorily, he metaphorically conceptualised the small ethnic groups in the north as minorities and devices, 'willing tools', for furtherance of the Islamic agenda. The rest of the south, including the south-west (Yoruba), south-east (Igbo) south-south (Igbo, Efik, Ibibio, Ijo, Urhobo, Itsekiri and others) should remain under the domination of the Hausa-Fulani Muslims of northern Nigeria. His negative perception of others enabled him to project upon them the imagery of implements used for manual labour. As implements, they would be used, abused or exploited and abandoned. Their voices would never be heard and their opinions should never count. They should neither control their affairs nor the affairs of the country, Nigeria. The hegemonic nature, willing submission of the small ethnic groups in the north was to be exploited for the pleasure of the Hausa-Fulani Muslim elites of the northern Nigeria.

ii. "Prophet Muhammed took slaves himself during Badr war. He killed many and because of this. I will also kill Obama, if I catch him. I will kill Jonathan, if I catch him. Just like you want to catch me and kill me. All those with turbans looking for opportunities to smear us, they are all infidels, betrayers and cheats like them, like Isreal people, Rome, England, they are all Christians and homosexuals. People of Germany, like Margret Thatcher, Ndume are all infidels". (Ejiofor: http://www.naij.com/65903.html)

The statements above were culled from Shekau's (leader of the Boko Haram Islamic terror group) video response following the aftermath of his abduction of over 200 Chibok school girls. He sought to justify his actions by deploying material action processes such as 'took', 'killed', 'catch' and 'smear'. He also deployed a relational process, i.e., 'are'. The video was recorded in secret and released online, because terrorism is a crime against humanity. The author needed to hide himself for such acts. Then, he referred to the Badr war, where the prophet himself, with a Muslim contingent routed a numerically stronger Meccan force near the oasis of Badr, southwest of Medina. They hauled home a great deal of booty and a few dozens of captives (Karsh, 2007: 14). The positive self-presentation and the negative other-presentation can readily be noticed in the text. A part of the implications of his statement was that he did well by abducting the school girls. Therefore, he would repeat such, once an opportunity re-occurs for it. The tone of the text is merciless. The word 'kill' re-occurs three times in the brief text. The persons to be killed are non-adherents to the strict injunctions of Islam, the infidels. His communicative acts are impolite. That implies that he had no regard for the others. He accused the others of aberrant practice such as homosexuality. Intolerance and violence pervade the entire text. He unambiguously asserted what he would do to the then President Jonathan. With the indicative statement of promise using 'will', he stipulated the condition under which he would not assassinate the President - if he failed to catch him. Then, he metonymically referred to his fellow Muslims, especially the imams and mullahs as 'all those with turbans' who speak against their terror acts as 
infidels. He went ahead to liken them to Christians. He perceived them as treacherous and deceitful people. He could not afford to tolerate the faiths and cultures of the others. All the countries he mentioned practice constitutional democracy. Which Shekau conceptualized as paganism (Ifesieh, 2015).

iii. "If what happens [happened] in 2011 should again happen in 2015, by the grace of God [Allah], the dog and the baboon will all be soaked in blood". (Ajayi, 2012 in Nigeria World)

This is a typical hate speech. Retired General Muhamadu Buhari then, but now President Muhamadu Buhari, Hausa-Fulani (northern Muslim) in the text referred to what happened in 2011, i.e., the general elections where he lost woefully to the ex-President Goodluck Ebele Jonathan. Buhari, in the text metaphorised the participants in Nigerian politics as 'the dog' and 'the baboon'; who he said 'will be soaked in blood', an indicative statement of promise. In other words, should he lose the election again in 2015 presidential elections, there would be carnage. What he meant exactly by 'the dog' and 'the baboon' could be imagined. The dog is known for its resilience, whereas the baboon is known for its craftiness and slyness. Perhaps, he and his northern supporters like Malam Nasir El-Rufai (cf. Punch, Jan. 28, 2014: http://punchng.com/news/sss-detains-el-rufai/), Vice Admiral Murtala Nyako (rtd.) (cf. Daily Post Newsletter, (online) 19 April, 2014: http://dailypost.ng/2014/19/pdp-running-government-impunity-ledevil-minded-persons-full-text-nyakos-letter/), Junaid Mohammed (Sunday Sun, Dec. o1, 2013: http://surnewsonline.com/new/2015-there//-bloodshed-jonathan-runs-warns-junaid-mohammed/), Professor Ango Abdullahi, Secretary of the Northern Elders Forum (cf. Vanguard, 15 October 2014: http://www.vanguardngr.com/2014/10/2015-well-regard-anyone-vote-pdp-enemy-north-nef/) and many more were the dogs whereas the People's Democratic Party's presidential flag bearer, ex-President Goodluck Jonathan and his supporters were the baboons. Buhari lost the presidential general elections serially in 2003, 2007 and 2011. General Muhamadu Buhari (rtd.) could not hide his sentiments towards ex-President Jonathan's presidential ambition in 2011 for he said:

"There may be no Nigeria. I draw parallel with Somalia so many times (Somalisation of Nigeria). I am scared about that. Somalia, they are one ethnic group, one religion, Islam, but for 18 years, Somalia became so selfish, so corrupt, so undisciplined and they have wrecked the country". (Anya, 2012)

One is inclined to think that Boko Haram is creation of the northern Islamic oligarchy in Nigeria, who enjoyed the hegemony of the nineteen northern states. However, with the rapid spread of Christianity even in the core Islamic parts of the north, the hubris and envy of Islamic irredentists were aroused. Thus, the aim of the Boko Haram would be to make the nation ungovernable for President Jonathan through unmixed political violence and unleashing of religious genocidal ravishments to reduce the presence and power to the sprawling Christianity with its accompanying western education in the region. Buhari, Babangida and some others were named as Boko Haram sponsors (cf. Samu: http://www.academic.edu; Asuelime, 2015: 1-10). With the 2015 presidential general elections won and lost with President Buhari declared winner by Independent National Electoral Commission (INEC) led by Prof. Atahiru Jega, one thought that Boko Haram attacks would stop and that the security of both human and material resources would improve, but the reverse has been the case. Boko Haram has transformed into Hausa-Fulani herdsmen, who kill farmers and destroy farmlands. Through terror attacks they engage in forced ejection and reoccupation (Onwuka May 1, 2018; Daily Trust https://www.pulse.ng/gist/crazy-herdsmen-muders-farmers-who-caught-him-raping-teenagegirl/6d76c71; Bewarang May 28, 2018).

iv. "Most of the inflection we have now is not demand driven but imported inflection. Once we can wean ourselves of import dependency, the inflation rates will come down". (Itsibor June 13, 2016)

The above statement reported by Itsibor was made by Victor Ogiemwonyi, Chief Executive Officer of Partnership Investment Company; Member, National Council of the Nigerian Stock Exchange. 
Therefore, his access to the presidency is undeniable. Invariably, he is one of those controlling the political discourse in the country. Ogiemwonyi speaks in defence of the executive government of which he is a member. He engages in the manipulation of the symptomatology of the economic hardship in Nigeria. Buhari led All Progressives Congress (APC) political party has been objectively blamed for Nigeria's economic woes in the last 5 years (2015-2020). It took President Buhari 6 months to form the cabinet of his government. That delay caused a lot of economic problems. The government does not also have any clear economic blueprint. For instance, the pump price of petrol was 86.50 naira per litre; but APC, claimed prior to the 2015 general elections that a litre ought to be sold much cheaper than 86.50 naira. Upon assumption of office, the Buhari led APC government increased the petrol price from 86.50 to 145.00 naira per litre. The increment was confusedly described by them as deregulation, partial deregulation, removal of subsidy, price modulation and price adjustment. The exchange rate was also increased from 195 naira to 250 naira per dollar (cf. Itsibor June 13, 2016). Soon, the prices changed again with the dollar gaining. (cf. Igiebor Jan. 18, Oct. 10 2016). The masses suffer the inflation.

In the text above text, Ogiemwonyi admits that there is economic difficulty. He said, "the inflation we have" ... the operational verb in the clause is 'have' which bears its full signification of possession therein. However, he denied demand increase as the cause of the inflation. Rather, he brings in a strange term "imported inflation" and accuses it for the hardship. Using high probability modality, i.e., "once we can wean...", he suggests that the inflation would subside and the economy would subsequently stabilise. The defence of the bad economy rendered here appears frenzied. It invariably makes allusion to the ban of all forms of provisions by the Federal Government without providing a conducive environment for the local industries to thrive. The security situation in Nigeria currently is terrifying. There are gunmen terror attacks, Hausa-Fulani herdsmen terror attacks, kidnapping, banditry, secret cultism and the debilitating boko haram terror attacks. In addition, eminent Nigerians say that the economy continuously deteriorates under Buhari (cf. Manuaka June 26, 2017; Atojoko July 4, 2016; Agbo Feb. 22, 2016; Aug. 8, 2016)

$v$. "The recent surgical operation against some judicial officers is specifically targeted at corruption and not at the judiciary as an institution". (Agbo Oct. 31, 2016)

The text above was made by Garba Shehu, Hausa-Fulani (northern Muslim), Special Assistant to the President on media and publicity upon the outcry of Nigerians that Buhari led APC government was out to forcefully coerce the judiciary to operate according to his whims. Shehu has a direct access to the presidency. Sequel to that, his utterances indicate the directions of the thinking and actions of the president. In the statement Shehu euphemistically tries to justify the ruthless Gestapo approach used by the Department for State Security (DSS) in variously breaking into the houses of 7 Nigerian judges (Agbo Oct. 31, 2016). Using the surgical operation metaphor, he likens the Federal Government headed by Buhari to a medical doctor who performs operations on patients in order to remove ailments from their bodies. However, by so doing he latently suggests that the Buhari executive has overreached itself, because the judiciary is an independent arm of government. The executive should not have interfered with the affairs of that arm of government. Nevertheless, he said that the operation was 'targeted at corruption' and not at the judiciary as an institution. In spite of that, it is the participants, who earn their living by operationalising the institution that constitute the institution. Judiciary cannot exist, if participants do not procedurally operate its objectives within its organogram as it relates to the other members of the society. It is a constitutional creation and it has a constitutionally provided mechanism for self-cleansing. It is the third estate of the realm (Nwabueze, 2007).

vi. "I belong to everybody and I belong to nobody ... constituencies that gave me $95 \%$ cannot in all honesty be treated [in the same manner] on some issues, with constituencies that gave me 5\%...". (Manuaka Nov. 21, 2016)

The text above was culled from President Buhari's speech in the early days of his $1^{\text {st }}$ tenure as the President of Federal Republic of Nigeria. The first statement in the text is a double sentence wherein 
the propositions expressed by the clauses are antithetical. Using the relational process of being, 'belong' he suggests firstly that he is a part of every constituency in Nigeria. Then, in second part of the double sentence, he negates the previous proposition using the logical negation, 'nobody'. Invariably, President Buhari suggests that he is accountable to none. However, in the subsequent part of the text he deploys material process, 'gave' and passivisation as noticed in 'be treated'. In the text, Buhari plays the percentages and therewith suggests bias against some constituencies. Dominance is again signalled here. Through passivisation, he obfuscates the agents he uses in his suggested biased treatment 'on some issues'. He uses modality element 'cannot' to demonstrate the probability of the biased treatment (injustice) as certain. The prepositional phrase 'in all honesty' accompanying the modality is for emphasis. From the text one can deduce that the citizenry are treated unequally under Buhari's regime. This reaffirms the dominant-minority relation in Nigeria's political discourse. For instance, the south populated mainly by Christians is marginalised in Buhari's government.

vii. "On the 2014 National Conference which many Nigerians are now calling for its implementation, [Ango] Abdullahi, at the birthday party of Edwin Clark in Abuja in May [2017], said the manner of selecting delegates to the 2014 constitutional conference was defective as the delegates were handpicked and thus its outcome could not be considered credible....

Anthony Sani, secretary of Arewa Consultative Forum, said even though the association doesn't believe that the problems of Nigeria could be solved by a constitutional conference, "as long as its promoters believe that it can further the cause of a united Nigeria, there will be no qualm"'. (Akaeze July 3, 2017)

The text above contains views of power elites from Northern Nigeria with regard to restructuring the country. The first paragraph contains the statements of Ango Abdullahi (northern Muslim) -former Vice Chancellor of Ahmadu Bello University, Zaria and spokesman of the Northern Elders Forum. He uses a relational process, 'was' whose accompanying argument is 'defective' to describe the conference. Next, he uses passivisation to obfuscate the agent involved the selection process of the conferees for the conference. However, the stance he takes as regards the credibility of that conference is obscure, for he uses the subjunctive element 'could' to indicate the certainty of the conference outcome which he negates with 'not'. On the contrary, many people believe in the credibility of the conference and are agitating for its implementation. The only people that do not want the implementation of the 2014 National Conference are many northern elements like Ango Abdullahi, who even had the opportunity to be a member of the conference, but refused.

The second paragraph contains the views of Anthony Sani, Secretary of Arewa Consultative Forum which is one of the formidable political associations in the northern Nigeria. It speaks the views of northern Nigeria on issues of national concerns. Ab initio, the association foreclosed any role at all that the conference can play in repositioning the country for greatness. Sani uses a conditional clause complex in the grammatical context of a mental process of COGNITION, 'believe' which subcategorises for "its promoters" as the Senser participant and the 'it,' i.e., the national conference as the Identified participant as well as Actor participant which is an argument of the Predicator, 'can further'. He applies high modality of certainty, 'can' as a modal auxiliary of the Predicator, 'further' a material action process whose Goal is 'the cause of a united Nigeria'. Next, he completes the clause complex with 'there will be no qualm'. The clause complex can simply be interpreted, that once the national conference speaks for national cohesion, then, there will be no problem. Already the use of the mental process of COGNITION in relation to the Identified participant is problematic because cognition is relative. It differs individually. In short, the northern Nigeria has a negative mental attitude towards restructuring the country.

\section{Discussion}

The stance of Hausa-Fulani northern Muslim power-elites in Nigeria generally betrays a strong inclination to dominance springing from ideological sources such as belief system and the political culture arising there from. The northern part of Nigeria predominantly practices Islam, which sees non 
adherents as infidels. An infidel in Islam should be summoned to believe, otherwise he should be conquered by force, because belief in Allah is 'immediate' and that is man's duty (Oshitelu, 2008: 157). This idea of dominance, signalled in positive self-presentation and negative other-derogation is being reconceptualised in different forms by both the northern Muslims and Hausa-Fulani power-elites. In text 1 under the Data Analysis and Presentation, the late Sir Ahamdu Bello makes a clarion call to his fellow northern elite-participants to resist any attempt at power shift to the south. He had already conceptualised the entirety of Nigeria as an estate, which should be dedicated to their late hero Uthman Dan Fodio. Dan Fodio was a leading Islamist who led a jihad that swept through almost the entire north and established a living tradition of reform and the basis of administrative system that exists in form of emirates and native authorities up to this day (cf. Hunwick, 1966: 292).

The reconceptualisation of dominance and determination to refuse the southern Nigerian participants access to political discourse are clear in Sir Ahmadu Bello's language. The political behaviour of the northern Nigeria power-elites is not different from his. President Buhari has often been accused of running a Fulani northern Nigeria agenda, part of which is the islamisation of Nigeria. The Federal Government under the leadership of President Buhari appoints his kinsmen and fellow adherents to the Islamic faith to the critical positions of the national security services. Chief of Army, Inspector General of Police, Minister of Defence, Minister of Internal Affairs, National Security Adviser, Director General, Department of State Service, Chief of Staff, Aide-De-Camp (ADC) to the President, Chief Security Officer (CSO) to the President, Private Secretary to the President, Protocol to the President, Director-General (DG) Customs, DG Prisons, DG immigration, the sensitive position of Minister of Petroleum and Ag. Director Economic and Financial Crimes Commission (EFCC) are all in the same hands. The islamisation of the entire organograms of the institutions entails the islamisation of the institutions and as a consequence the islamisation of the government and by the reason thereof the islamisation of the country (Nwabueze Oct. 24, 2016). These appointments by the president and statements from the northern elites are in violation of fundamental objectives and directive principles of state policy to the effect that 'the state shall foster a feeling of belonging and of involvement among the various peoples of the Federation...' (1999 Constitution of the Federal Republic of Nigeria).

The activities of the Boko Haram ties into power and dominance, too. The conceptualisations are marshalled out predominantly in material action processes like 'kill' 'take' "catch". They kill infidels; take sex slaves and catch Jonathan, Obama or any of their likes whose beliefs are different from theirs. Boko Haram is said to have been sponsored by northern political elites in other to frustrate the exPresident Jonathan's regime. Jonathan is from the southern Nigerian which should not be tolerated (see text 2).

General Buhari did not mince words prior to 2015 general elections that should what happened in 2011 happen in 2015 'both the monkey and the baboon would be soaked in blood'. This hate speech is in consonance with the northern elites' political agenda of exclusion and resistance against the southern Nigerian rulership. Due largely to avarice and ignorance, the resistance of Jonathan's regime was supported by some power elites form the southern Nigeria prior to the 2015 general elections. Notably, ex-President Obasanjo and Ahmed Tinubu worked tirelessly to ensure that Jonathan did not return to power in 2015.

Nevertheless, the infringement of the fundamental objectives and directive principles of Nigeria's constitutional democracy by the Buhari regime has pitched the citizenry against his government. There are intensified agitations for restructuring of Nigeria (Agbo Aug. 21, 2017; Agbo July 24, 2017; Agbo June 5, 2017). The ambers of resource control are further fanned (Darah, 2014; Obe Feb. 22, 2016). There is a renewed agitation for the Biafran state by the Indigenous People of Biafra (IPOB) who rightly feel grossly marginalized in the national political discourse (cf. texts 6 and 7 ). The political misrule (cf. texts 5 and 4) and infringement of the fundamental principles of Nigeria's constitutional democracy has cataclysmic effects: the Nigerian security architecture has been slanted towards ethnicism; therefore, it is difficult to penalise high profile infractions in the institution. This has led to a very porous security system (Salkida Jan. 3, 2019). Besides, Buhari's administration engages in negotiations with terrorists and pays ransoms to them contrary to the international best practices (Sekulow, 2014). There is low 
foreign capital investment which affects the economy negatively; the citizenry lives in fear; misery index is high; more and more people are getting poorer and poorer; the Nigerian currency depreciates in relation to the other currencies, there are job losses, high unemployment and school drop outs. Educational institutions are seriously underfunded. In spite of all these, the northern Muslim powerelites generally stand in defence of the regime.

\section{Conclusion}

Nigeria's evolving democracy is characterized by constitutional infractions and politics of dominance and inequality in favour of the northern Muslim power-elites, especially the Islamic oligarchy in the northern Nigeria. Over the years, the Hausa-Fulani Muslim enjoys hegemonic dominance in Nigeria's political discourse. This has become a challenge not only to the marginalised southern Nigeria, but also to the entire northern Nigeria. This is so, because in the attempt by the northern political eliteparticipants to retain the position of dominance in the political discourse, they resorted to violent conceptualisations as evident in the language of the elites (cf. texts 1, 2, 3, and 5). The peoples worse hit by the events that accompany the conceptualisations are still the northerners, but because the country is one political entity within which there are various systems of meanings, which interrelate, the entire citizenry is affected by the happenings in the country. For the southern Nigeria-participants to locate themselves into the position of control of political discourse, they have to reconceptualise their political agenda and strategy. As a take-off point the national assembly members from the south should unanimously engage their colleagues from northern ethnic minorities under the hegemony of the northern Islamic oligarchy with the objective of conscentizing them about their freedom, rights and power. This will not only break the rank and file of the oligarchy, but also diminish the political clout of their power-elites. Subsequently, the northern ethnic minorities should jointly with the southern Nigeria-participants demand for both fiscal and geopolitical restructuring of Nigeria. Doing it disjointedly will be unsuccessful as evident in the Biafran attempt (cf. Achebe, 2012; Boro, 1982) because the soldiers who ruled the country by decrees for about 3 decades were predominantly northern Muslims. They handed over a biased constitution tilted in favour of the north to their civilian successors. The constitution recognises 19 states in the north, plus the Federal Capital Territory (FCT), Abuja, a city state in the north and only 17 in the south. Each state sends three senators to the upper house, i.e., the senate while FCT sends only one. Sequel to that, whereas the north has 58 senate members, the south has only 51 out of the 109 members. A similar constitutional injustice occurs in the lower house, where the constituencies are gerrymandered overwhelmingly in favour of the north, i.e., 191 constituencies for the north, but 169 to the south. Nevertheless, once the northern ethnic minorities $\{($ domiciled in the following states: Niger (10- constituencies), Kogi (9-), Kwara (6-), Plateau (8-), Benue (11-), Nasarawa (5-), and Federal Capital Territory-FCT (2-) i.e., the so called north central geopolitical zone) $\}$ team up politically with the south, they will change the old order and tilt the balance of power in their favour, because they will become more than the Hausa-Fulani Muslim north, numerically: 51 constituencies would have been subtracted from the 191, thereby reducing the northern constituencies to 140 and increasing the new political block to 220. In a similar manner, 19 senate members would have been moved from the north central to the new power block. This would make the number of senators from the new political block 70 and the ones from the remainder north 39. Then, they can democratically have a stronger voice than the dominant northern oligarchy who has been controlling the access to political discourse. Therefore, the involvement of the marginalized northern minorities by the south in the political re-engineering will help to achieve the goal of equitable access to political discourse in Nigeria.

\section{References}

1999 constitution of the Federal Republic of Nigeria.

Achebe, C. 2012. There Was a Country: a Personal History of Biafra. London: Penguin. 
Adejare, O. 1992. Language and Style in Soyinka: a Systemic Text Linguistic Study of the Literary Idiolect. Ibadan Heinemann.

Agbo, A. Aug. 8, 2016. The road to economic depression. TELL. www.tell.ng

Agbo, A. Feb. 22, 2016. The budget's comedy of errors. TELL. www.tell.ng

Agbo, A. Interview with Nnia Nwodo. Aug. 21, 2017. I see no future for Nigeria, unless... TELL. www.ng

Agbo, A. July 24, 2017. Why Nigeria must change. TELL. www.tell.ng

Agbo, A. June 5, 2017. Playing politics with coup. TELL. www.tell.ng

Agbo, A. Oct. 31, 2016. DSS' vendetta against judges. TELL. www.tell.ng

Ajayi, F. May 26, 2012. Buhari and the 2015 'the dog and the baboon' bloody election. Nigeria World. Retrieved 05.07.2019 URL: http://chatafrik.com/articles/nigerian-affairs/buhari-and-the-2015-the-dog-and-thebaboon-bloody-election\#.XR9LQ3so_IU

Akaeze, A. July 3, 2017. Why the north is afraid. TELL. www.tell.ng

Alexander, A. and Renton, D. 2002. Globalization, imperialism, and popular resistance in Egypt, 1880-200o. Zeilig, L. (ed.). Class Struggle and Resistance in Africa. Cheltenham, UK: New Clarion Press. pp. 87-115.

Anya, V. 2012. Making Nigeria ungovernable for president Jonathan. Daily Independent. Retrieved June, 23,2014 URL: http://dailyindependentnig.com/2012/o6/making-nigeria-ungovernable-for-president-jonathan

Appadorai, A. 2004. The Substance of Politics. Oxford: Oxford University Press.

Asuelime, L. and Adekoye, R. 2015. Perception of boko haram in northern Nigeria and the 2015 presidential election. AFRICA INSIGHT. Africa Institute of South Africa. Vol., 45 (2), pp: 1-10.

Atojoko, S. July 4, 2016. Can new forex regime save economy? TELL. www.tell.ng

Bakunin, M. 2003. From God and the state. Blaisdell, B. (ed.). 2003. The Communist Manifesto and other Revolutionary Writings: Marx, Marat, Paine, Mao, Gandhi and Others. Mineola: Dover. pp. 187-199.

Banda, A. 2002. Foreword. Zeilig, L. (ed.). Class Struggle and Resistance in Africa. Cheltenham, UK: New Clarion Press. pp. ix-xvi.

Barnes, S. 2018. Copula variation in Asturian Spanish and the multidimensionality of stance taking in interaction. Journal of Sociolinguistics. Vol., 22, No. 1, pp. 29-54.

Bewarang, S. May 28, 2018. Plateau massacre: armed Fulani herdsmen attacks and killings targeted at Christians across Nigeria. Press Release. Church Denominational Heads in Plateau and Christian Association of Nigeria (CAN), Plateau State.

Black, M. 1979. More about metaphor. Metaphor and Thought. Andrew Orthony. Ed. London: Cambridge University Press. 19-43.

Blaisdell, B. (ed.). 2003. The Communist Manifesto and other Revolutionary Writings: Marx, Marat, Paine, Mao, Gandhi and Others. Mineola: Dover.

Bloor, M. and Bloor, T. 2007. The Practice of Critical Discourse Analysis: An Introduction. London: Hodder Arnold.

Boro, I. J. A. 1982. The Twelve Day Revolution. Edited by Tebekaemi, T. Benin: Idodo Umeh Publishers

Chandler, D. 1994. The Sapir-Whorf Hypothesis. Retrieved June, 2007 URL: http://www.aber.acuk/vdoc/whorf.html

Cornevin, M. 1981. Apartheid -- Mythos und Wirklichkeit. Wuppertal: Hammer.

Cresswell, J. W. 1998. Qualitative Inquiry and Research Design: Choosing among Five Traditions. Thousand Oaks, CA: Sage Publications.

Daily Post News Letter. (Online). April 19, 2014 URL: http://dailypost.ng/2014/19/pdp-running-governmentimpurity-led-evil-minded-persons-fall-text-Ayakos-letter/

Daily Trust. Retrieved 22.06.2019 URL: https://www.pulse.ng/gist/crazy-herdsmen-muders-farmers-who-caughthim-raping-teenage-girl/6d76c71

Danton, G. J. 2003. Dare, dare again, always dare. Blaisdell, B. (ed.). 2003. The Communist Manifesto and other Revolutionary Writings: Marx, Marat, Paine, Mao, Gandhi and Others. Mineola: Dover. pp. 90-91.

Darah, G.G. 2014. The Niger Delta: Resource Control and the Quest for Justice. Ibadan: Kraft Books.

Desmoulins, C. 2003. Live free or die. The Communist Manifesto and other Revolutionary Writings: Marx, Marat, Paine, Mao, Gandhi and Others. Mineola: Dover. pp. 67-69.

Dwyer, P. 2002. South Africa under the ANC: still bound to the chains of exploitation. Zeilig, L. (ed.). Class Struggle and Resistance in Africa. Cheltenham, UK.New Clarion Press. pp. 187-211.

Dzurgba, A. 2008. Nigerian Politics and Ethical Behaviour. Ibadan: John Archers.

Ejiofor, C. Boko Haram threaten President Jonathan and other world leaders. Retrieved 10.10.2014 URL: http://www.naij.com/65903.html

Encyclopedia Americana International Edition. Vol., 8. 2004. Danbury Connecticut: Scholastic Library Publishing Inc.

European Union $\quad$ Election $\quad$ Observation $\quad$ Mission https://eeas.europa.eu/sites/eeas/files/nigeria_2019_eu_eom_final_report-web.pdf 
Fairclough, N. 1995. Critical Discourse Analysis: The Critical Study of Language. London: Longman.

Fairclough, N. 2001. Language and Power. Second edition. Harlow: Longman, Pearson Education.

Glaser, B. G. and Strauss, L. S. 1967. The Discovery of Grounded Theory: Strategies for Qualitative Research. Piscataway, New Jersey: Transaction.

Goddard, C. 1998. Semantic Analysis: a Practical Introduction. Oxford: Oxford University Press.

Guevara, C. 2003. Colonialism is doomed. Blaisdell, B. (ed.). 2003. The Communist Manifesto and other Revolutionary Writings: Marx, Marat, Paine, Mao, Gandhi and Others. Mineola: Dover. pp. 265-279.

Gwisai, M. 2002. Revolutionaries, resistance and crisis in Zimbabwe. Zeilig, Leo (ed.). Class Struggle and Resistance in Africa. Cheltenham, UK: New Clarion Press. pp. 219-251.

Halliday, M. A. K. 1985. An Introduction to Functional Grammar. London: Edward Arnold.

Halliday, M. A. K. Revised by C. M.I.M. Matthiessen. 2004. An Introduction to Functional Grammar. Third Edition. London: Hodder Education.

Halliday, M.A.K. 1978. Language as Social Semiotic: the Social Interpretation of Language and Meaning. London: Edward Arnold

Halliday, M.A.K. and Hasan, R. 1991. Language, Context and Text: Aspects of Language in a Social-Semiotic Perspective. Oxford: Oxford University Press.

Hampsher-Monk, I. 20o6. A history of Modern Political Thought: Major Political Thinkers form Hobbes to Max. Malden: Blackwell Publishing

Haralambos, M.; Holborn, M. and Heald, R. 20o8. Sociology: Themes and Perspectives. $7^{\text {th }}$ Edition. Hammersmith: Collins.

Howard, P. W. and Hussein, M. M. 2013. Democracy's Fourth Wave? Digital Media and the Arab Spring. Oxford: Oxford University Press.

Hunwick, J. O. 1966. The nineteenth-century jihads. Anene, J. C. and Brown, G. (eds.). Africa in the Nineteenth and Twentieth Centuries. Ibadan: University of Ibadan Press.

https://www.iri.org/sites/default/files/nigeria_election_report_updated.pdf;

https://www.sunnewsonline.com/2019-electoral-violence-worse-than-2015-eisa-eom/;

https://dailypost.ng/2019/02/25/nigeria-elections-international-observer-group-gives-damning-report/

Ifesieh, E. C. 2013. Translatability of Metaphors: Contrasting German Editions of Things Fall Apart, (das Alte stürzt) and The Famished Road, (die hungrige Strasse). Saarbrücken, Deutschland: LAP LAMBERT.

Ifesieh, E. C. 2015. Challenges of semantic extensions of jihad power symbols vis-à-vis boko-haram. European Journal of Language Studies. Vol.2, No.1, pp.42-55.

Ifesieh, E. C. 2018. Personal names as sociopolitical and cultural metaphors: a case study of Ebedei-Umueziogoli. Journal of the Linguistic Association of Nigeria (JOLAN). Supplement III. pp. 68-84.

Igiebor, N. Jan. 18, 2016. The message from Washington. TELL. www.tell.ng

Igiebor, N. Oct. 10, 2016. A mirage called change. TELL. www.tell.ng

Itsibor, M. June 13, 2016. Battling to save the economy. TELL. www.tell.ng

Iyayi, F. 1980. Violence. Ikeja, Lagos. Longman.

Karsh, E. 2007. Islamic Imperialism: a History. New Haven: Yale University Press.

Larmer, M. 2002. Resisting the state: the trade union movement and working class politics in Zambia, 1964-91. Zeilig, L. (ed.). Class Struggle and Resistance in Africa. Cheltenham, UK: New Clarion Press. pp. 157-177.

Lenin, V.I. 2003. The task of the proletariat in the present revolution. Blaisdell, B. (ed.). 2003. The Communist Manifesto and other Revolutionary Writings: Marx, Marat, Paine, Mao, Gandhi and Others. Mineola: Dover. pp. 227-231.

Locke, T. 2004. Critical Discourse Analysis. London: Continuum.

Maffi, L. 1999. Linguistic diversity. Posey, D. A. (ed.). Cultural and Spiritual Values of Biodiversity. Nairobi, Kenya: UNEP. pp. $21-57$.

Malmkjaer, K. 2002. The Linguistics Encyclopedia. Second Edition London: Rutledge.

Manuaka, T. June 26, 2017. Managing the tottering economy. TELL. www.tell.ng

Manuaka, T. Nov. 21, 2016. The odds against Buhari’s \$30 billion loan. TELL. www.tell.ng

Noueihed, L. and Warren, A. 2012. The Battle for the Arab Spring: Revolution, Counter-Revolution and the Making of a New Era. Yale: Yale University Press. pp. 304.

Nwabueze, B. 2007. The Second Justice Kayode Eso Lectures: the Judiciary as the Third Estate of the Realm. Ibadan: Gold Press.

Nwabueze, B. Oct. 24, 2016. How crisis in UNILAG accelerated 1966 coup.Retrieved 24.10.2016 URL: http://www.vanguard.com/2016/10/howcrisis-in-unilag-accelerated-1966-coup/

Obe, E. Feb. 22, 2016. Again, temper creeps in the creeks. TELL. www.tell.ng

Ogden, C.K. and Richards, I.A. 1946. The Meaning of Meaning. $8^{\text {th }}$ Edition New York: Harcourt Brace and World. 
Okri, B. 1996. The Famished Road. Ibadan: Spectrum Books.

Omotor, D. G. A. 2019. A thrifty north and an impecunious south: Nigeria's external debt and the tyranny of black political economy. $81^{\text {st }}$ in the Series of Inaugural Lectures of Delta State University, Abraka, Nigeria. Abraka: University Printing Press.

Onwuka, A. May. 1, 2018. Farmer-herder clashes or ethnic cleansing? Daily Trust. Retrieved 22-06-2019 URL: https://punch.com/herder-farmer-clashes-or-ethnic-cleansing

Oshitelu, G.A. 2008. The Philosophy of Religion: an Introduction. Ibadan: Hope publications.

Parrot Newspaper. Oct. 12, 1960.

Pinker, S. 1994. The Language Instinct. Harmondsworth: Pengium.

Proudhon, P-J. 2003. What is property? Blaisdell, B. (ed.). 2003. The Communist Manifesto and other Revolutionary Writings: Marx, Marat, Paine, Mao, Gandhi and Others. Mineola: Dover. pp. 102-121.

Punch. Jan. 28, 2014 URL: http://punchng.com/news/sss-detains-el-rufai/

Rojo, L. M. and Molina, C. 2018. Cosmopolitan stance negotiation in multicultural academic settings. Journal of Sociolinguistics. Vol., 21, No. 5. pp. 672-695.

Rottenberg, A. T. and Winchell, D. H. 2006. Elements of Argument: a Text and Reader. $8^{\text {th }}$ Edition Boston: Bedford/St. Martin's.

Safra, J. E. 2010'. The New Encyclopaedia Britanica. Vol. 1. Chicago: Encyclopedia Britanica, Inc.

Safra, J. E. 2010'. The New Encyclopaedia Britanica. Vol. 4. Chicago: Encyclopaedia Britanica Inc.

Salkida, A. Jan. 3, 2019. Explosive; boko haram winning via funding and weaponry from Nigerian govt, helps communities troops plunder for food. Desert Herald. Retrieved Jan. 3, 2019 URL: http://saharareporters.com/2019/o2/special-report-why-troops-are-losing-ground-iswap

Samu, M. D. Boko haram tactical and strategic systems. Retrieved 22.06.2019 URL: http://www.academia.edu

Sekulow, J. 2014. Rise of ISIS: a Threat We Can't Ignore. New York: Howard Books.

Sheyholislami, J. Critical discourse analysisi. Retrieved 04.07.2019 URL: http://www.carleton.ca/ᄀjsheyhol/cda.htm

Sunday Sun. Dec. 01, 2013 URL: http://sunnewsonline.com/new/2015-there//-blooshed-jonathan-runs-warnsjunaid-mohammed/

Sweijs T., Oosterveld, W. T., Knowles, E. and Schellenkes, M. 2014. Why Are Pivot States so Pivotal?: the Role of Pivot States in Regional and Global Security. Hague: The Hague Centre for Strategic Studies (HCSS).

Tomlin, R. S., Forrest, L., Pu, M. M. and Kim, M. H. 1997. Discourse semantic. Discourse as Structure and Process. Discourse Studies: a Multidisciplinary Introduction. Vol., 1. London: SAGE Publications. pp. 63-111.

Trotsky, L. 2003. The proletariat and the revolution. Blaisdell, B. (ed.). 2003. The Communist Manifesto and other Revolutionary Writings: Marx, Marat, Paine, Mao, Gandhi and Others. Mineola: Dover. pp. 204-212.

van Dijk, T. A. 1993. Principles of Critical Discourse Analysis. DISCOURSE and SOCIETY. Vol., 4 (2) 249-283.

van Dijk, T. A. 1995 Discourse semantics and ideology. Discourse E Society. London: SAGE. Vol. 6(2). 243-289.

van Dijk, T. A. 1997. The study of discourse. van Dijk, T. A. (ed.). Discourse as Structure and Process. Discourse Studies: a Multidisciplinary Introduction. Vol., 1. London: SAGE Publications. pp. 1-34.

van Dijk, T. A. 2006. Discourse and manipulation. Discourse \& Society. London: SAGE. Vol. 17(2). 359-383.

van Dijk, T. A. 2008. Discourse, knowledge, power and politics: Towards Critical Epistemic Discourse Analysis. Lecture CADAAD, Hertfordshire.

van Dijk, T. A. 2009. Discourse, Ideology and Context. Folia Linguistica. Berlin: Mouton de Gruyter. XXXV/1-2.

Vanguard. Oct. 15, 2014 URL: http://www.vanguardngr.com/2014/10/2015-well-regard-anyone-vote-pdp-enemynorth-nef

Viinikka, J. 2002. There shall be no property: trade unions, class and politics in Nigeria. Zeilig, L. (ed.) Class Struggle and Resistance in Africa. Cheltenham, UK: New Clarion Press. pp. 122-149.

Voltaire. 2003. Policy. Blaisdell, B. (ed.). 2003. The Communist Manifesto and other Revolutionary Writings: Marx, Marat, Paine, Mao, Gandhi and Others. Mineola: Dover. pp. 34-40. 